\title{
Effects of temperature and salinity on larval development of Elminius modestus (Crustacea, Cirripedia) from Helgoland (North Sea) and New Zealand
}

\author{
J. Harms \\ TH-Darmstadt, Zoologisches Institut; Schnittspahnstr. 10, D-6100 Darmstadt, \\ Federal Republic of Germany \\ and \\ Biologische Anstalt Helgoland (Meeresstation); D-2192 Helgoland, \\ Federal Republic of Germany
}

\begin{abstract}
Larvae of Elminius modestus (Darwin) from four different populations (Portobello, Leigh, Doubtless Bay [New Zealand] and Helgoland [North Sea]) were reared at different salinity and temperature combinations. The larvae of $E$. modestus from Helgoland developed successfully at a wide range of temperature $\left(6^{\circ}\right.$ to $\left.24^{\circ} \mathrm{C}\right)$ and salinity $(20$ to $50 \%$ S). Mortality was highest at $10 \%$ $\mathrm{S}$; only at $12^{\circ}$ and $18^{\circ} \mathrm{C}$ did a small percentage develop to the cypris. The larvae from New Zealand were reared at a temperature range of $12^{\circ}-24{ }^{\circ} \mathrm{C}$ at 20,30 and $40 \% \mathrm{~S}$; mortality increased in all populations at all salinities with decreasing temperature and was extremely high at $12{ }^{\circ} \mathrm{C}$ and $40 \%$ $\mathrm{S}$. The temperature influence on larval duration could be described in all cases by a power function. No significant differences in temperature influences on developmental times between the tested salinities were found, except for the Portobello population at $20 \%$ S. Significant differences were found in the temperature influence on larval development between the populations from Helgoland and the North Island of New Zealand (Leigh, Doubtless Bay). No differences were found between the Helgoland and Portobello population. The pooled data for the temperature influence on the larval development of the three tested New Zealand populations at 20,30 and $40 \% \mathrm{~S}$ and the pooled Helgoland data at 20,30 and $40 \%$ S show highly significant differences.

Larval size (stage VI) was influenced by experimental conditions. The larvae grew bigger at low temperatures and attained their maximum size at $30 \% \mathrm{~S}$ (Helgoland). There was a strong reduction in larval size at temperatures from $18^{\circ}$ to $24^{\circ} \mathrm{C}$. The larvae of the New Zealand populations were smaller than those from Helgoland. The greatest difference in size existed between the larvae from Portobello and Helgoland.
\end{abstract}

\section{INTRODUCTION}

Elminius modestus (Darwin) is a very common species throughout New Zealand (N. Z.), where it occurs on a wide range of substrates in the mid- and shallow sublittoral zones (Luckens, 1976; Foster, 1978; Moore, 1944; Morton \& Miller, 1968). The distribution of E. modestus in Australia is restricted to shipping ports and it is possible that shipaided dispersal from N.Z. to Australia has occurred (Foster, 1980, 1982). Similarly, E. modestus has also supposedly introduced itself to Europe by settling on ships coming from N. Z. (Bishop, 1947; Crisp, 1958), and was first recorded in 1945 in Chichester 
Harbour (England) by Bishop (1947). Since 1945, E. modestus has spread rapidly throughout Europe (Barnes \& Barnes, 1960, 1961, 1965a, 1969; Bames \& Powell, 1966; Barnes \& Stone, 1972; Barnes et al., 1972; Bishop, 1954; Boschma, 1948; Connell, 1955; Crisp, 1959a, 1960; Crisp \& Southward, 1959; Den Hartog, 1953, 1956; Fischer-Piette \& Forest, 1961; Hiscock et al., 1978; Jones, 1961; Powell, 1960; Stubbings, 1950).

E. modestus was first recorded at Helgoland in 1955 (DenHartog, 1959; Kühl, 1963), and has since become a common species in the inter- and subtidal zone around Helgoland (Anger, 1978; Harms \& Anger, 1983; Janke, 1986).

Genetic divergence of these separated populations in N. Z. and Europe, which might be caused by the genetic equipment of the invaders and/or by different natural selection in the two habitats (Crow \& Kimura, 1970), has been tested (Flowerdew, 1984; Ritz \& Foster, 1968) and no indication of genetic divergence was found (Flowerdew, 1984).

The present study describes and compares the influence of water temperature and salinity on larval development of three populations of E. modestus from N. Z. (Portobello - Otago harbour; Leigh - Snells Beach; Doubtless Bay) and one from Europe (Helgoland) (Fig. 1).

\section{MATERIALS AND METHODS}

Elminius modestus develops through six nauplius stages. The first larval stage is not considered here because it lasts only a few hours and does not feed (Harms, 1984). Experiments were terminated when the larvae reached the cypris stage. Larvae of $E$. modestus were reared individually in small glass bowls $(4-5 \mathrm{ml})$ at different salinities $(10,20,30,40,50 \% \mathrm{~S})$ in constant-temperature rooms $\left(6^{\circ} \mathrm{C}, \mathrm{LD} 14: 10\right.$ and $9^{\circ}, 12^{\circ}, 18^{\circ}$ and $24^{\circ} \mathrm{C}, \mathrm{LD}$ 17:7). The salinities were obtained by mixing concentrated seawater (acquired by deep freezing seawater) with distilled water.

Larvae were not previously adapted to the salinities. The water was changed every second day and the larvae were fed with Skeletonema costatum $\left(10^{5}\right.$ cells per $\left.\mathrm{ml}\right)$. Antibiotics were added at a concentration of $0.3 \mathrm{ml}$ Crystamycin $/ 1$ seawater $(300 \mathrm{mg}$ Penicillin $\mathrm{G}$ and $500 \mathrm{mg}$ Streptomycin in $4 \mathrm{ml}$ destilled water). Culture bowls were checked daily for exuviae, though twice daily at $24^{\circ} \mathrm{C}$. 75 larvae were reared for the Helgoland population in each experimental set at $6^{\circ}, 12^{\circ}, 18^{\circ}$ and $24{ }^{\circ} \mathrm{C}$, and 25 at $9{ }^{\circ} \mathrm{C}$. Experiments were terminated when the larvae reached the cypris stage. For more details see Harms (1984).

For the experiments done at the Marine Institutes of Portobello (University of Otago) and Leigh (University of Auckland) adults of E. modestus were collected from the field and ripe eggs were collected. Only larvae which hatched during the first hour were used for experiments. The experiments in Portobello ( $\mathrm{n}=55$ at $12^{\circ}, 15^{\circ}$ and $18^{\circ} \mathrm{C} ; \mathrm{n}=22$ at $16^{\circ}$ and $24^{\circ} \mathrm{C}$ LD 15:9) were done in "temperature controlled water-baths" and in Leigh (n $=36$ at $12^{\circ}, 15^{\circ}, 18^{\circ}$ and $24^{\circ} \mathrm{C}$ LD 12:12) in "temperature controlled boxes" at 20,30 and $40 \% \mathrm{~S}$. The relatively small culture bowls $(4-5 \mathrm{ml})$ had to be checked in both cases at room temperature $\left(18^{\circ} \mathrm{C}\right)$, causing temperature changes of the culture medium. Because such variations can have a strong influence on developmental time (Costlow \& Bookout, 1971; Sastry, 1979), adult E. modestus from Portobello, Leigh and Doubtless Bay were taken to the Marine Station Helgoland (F. R. G., North Sea) to repeat the experiments under conditions identical to those for the Helgoland population at $12^{\circ}, 18^{\circ}$ and $24^{\circ} \mathrm{C}$ and 20,30 and $40 \% \mathrm{~S}$. 


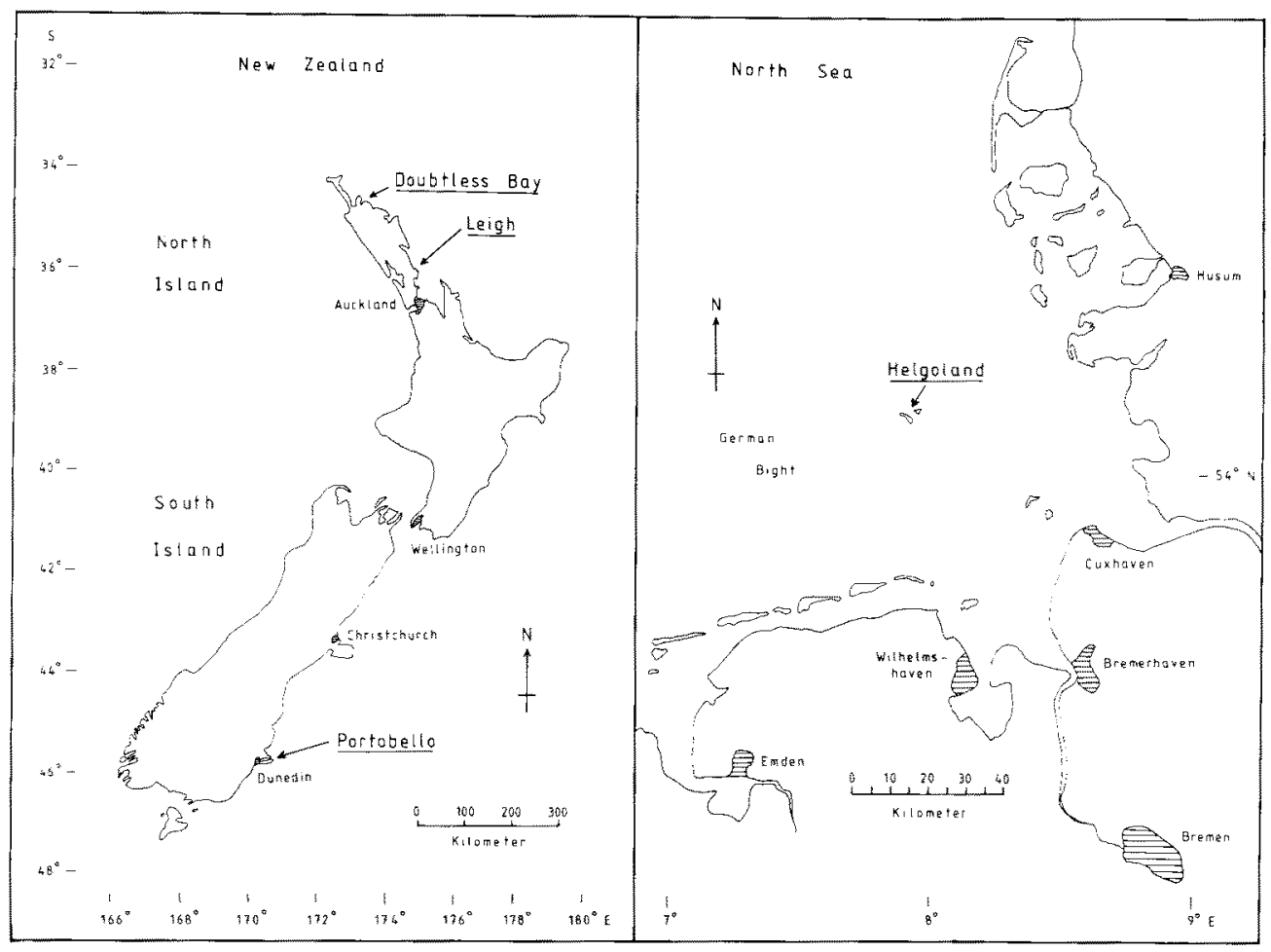

Fig. 1. Map of New Zealand and the German Bight (Europe) with the locations of the tested populations of Elminius modestus

The origin of the tested populations is shown in Figure 1. The natural range of water temperatures and salinity at Helgoland, Portobello and Leigh is given in Figure 2. Doubtless Bay conditions resemble those of Leigh.

The adults from N.Z. were kept at the Marine Station Helgoland at constant $15^{\circ} \mathrm{C}$ for about three months in a flow-through-system before newly hatched larvae were taken for experiments. 24 larvae of the N.Z. populations were reared at the Marine Station Helgoland at each combination.

The growth rate of the larvae was determined by measuring the breadth of the carapace with an okular micrometer. Carapace breadth is a good indicator because of its relatively small variation within single experimental sets (Harms, 1982).

\section{RESULTS}

\section{Helgoland population}

The time span for the development of the naupliar stages II-VI at different combinations of salinity and temperature are shown in Figure 3. Developmental time of the naupliar stages increases with decreasing water temperatures, and is shortest between 


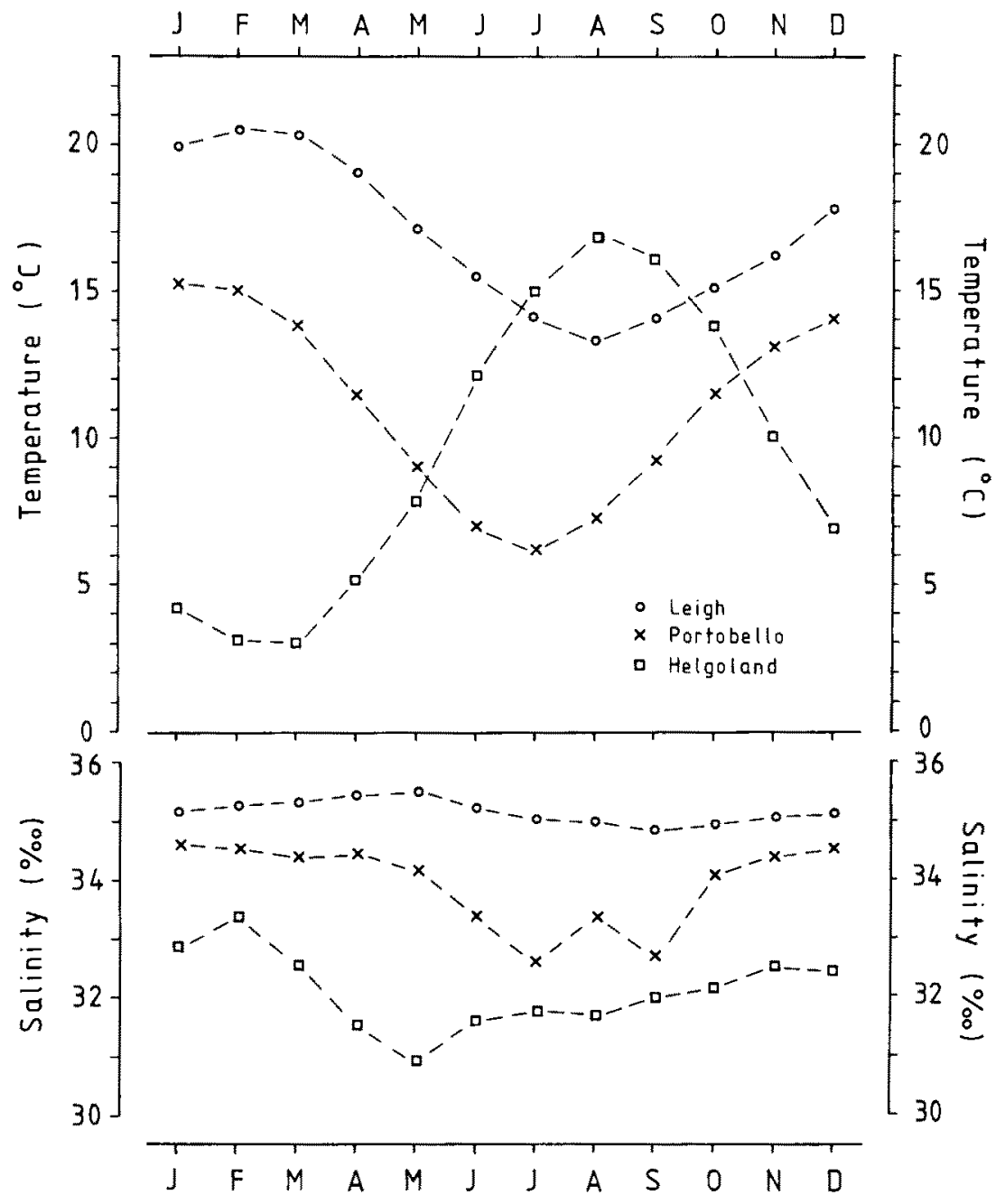

Fig. 2. Annual variation of water temperature and salinity at Helgoland $(\square$, according to Hickel \& Mangelsdorf, 1980), Portobello ( $x$, according to Slinn, 1968) and Leigh (o, according to Ballentine, 1983)

20 and $40 \% \mathrm{~S}$. The temperature influence at the different salinities can be described by a power function. Table 1 shows the function constants $\mathrm{b}$ and $\mathrm{m}$ and correlation coefficient ( $r$ ) for the developmental time of the single naupliar stages as well as for the total development from nauplius II to the cypris stage. No differences in temperature influence exist between the tested salinities. The $\mathrm{Q}_{10}$-values for the temperature influence between $6^{\circ}, 12^{\circ}$ and $24^{\circ} \mathrm{C}$ on the duration of total development lie between 2.2 und 3.4, depending on the temperature range and salinity (Table 7). The regression line for the time of total development from nauplius II to the cypris is compared in Figure 11 with the data of the N.Z. populations. 


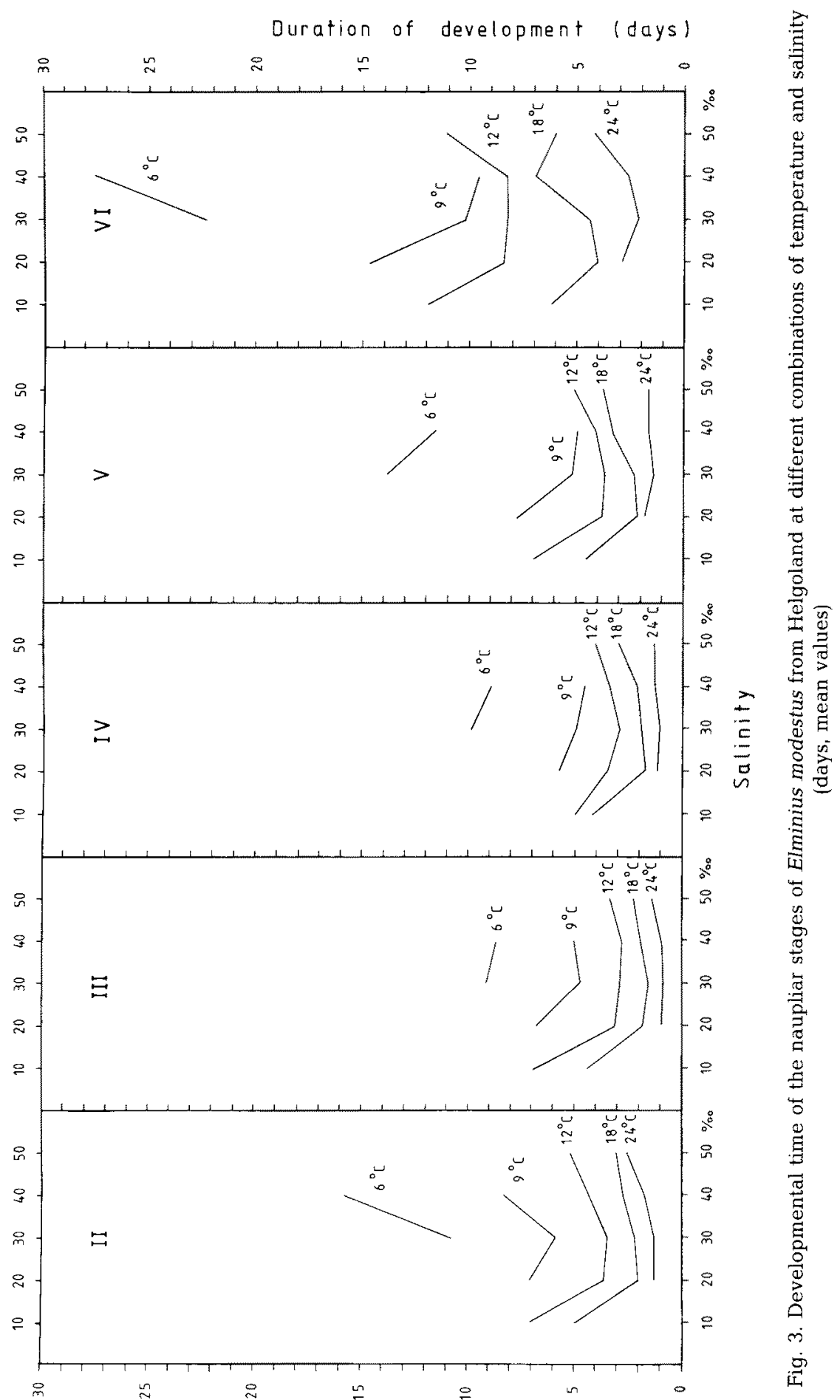


Table 1. Values of power function $\left(D=b t^{m}\right)$ for thermal influence $(t)$ on larval development (D) of Elminius modestus from Helgoland for the temperature interval $6^{\circ}$ to $24^{\circ} \mathrm{C}$ at $10,20,30,40$ and $50 \% \mathrm{~S}$. (b and $\mathrm{m}$ are constants, $\mathrm{r}=$ correlation coefficient, $\mathrm{p}=$ confidence interval)

\begin{tabular}{|c|c|c|c|c|c|c|c|c|c|}
\hline $\begin{array}{c}\text { Salinity } \\
(\% \circ)\end{array}$ & $b$ & $\mathrm{~m}$ & $r$ & $\mathrm{p}$ & $\begin{array}{c}\text { Salinity } \\
(\% 0)\end{array}$ & $\mathrm{b}$ & $\mathrm{m}$ & $\mathbf{r}$ & $\mathrm{p}$ \\
\hline \multicolumn{6}{|c|}{ Nauplius stage II } & \multicolumn{4}{|c|}{ Nauplius stage III } \\
\hline 20 & 225 & -1.63 & -0.99 & $<0.001$ & 20 & 369 & -1.87 & -0.94 & $<0.001$ \\
\hline 30 & 158 & -1.51 & -0.99 & $<0.001$ & 30 & 176 & -1.65 & -0.97 & $<0.001$ \\
\hline 40 & 253 & -1.58 & -0.99 & $<0.001$ & 40 & 155 & -1.59 & -0.97 & $<0.001$ \\
\hline 50 & 68 & -1.05 & -0.97 & $<0.02$ & 50 & 42 & -1.05 & -0.90 & $<0.05$ \\
\hline \multicolumn{6}{|c|}{ Nauplius stage IV } & \multicolumn{4}{|c|}{ Nauplius stage $V$} \\
\hline 20 & 175 & -1.58 & -0.95 & $<0.001$ & 20 & 119 & -1.35 & -0.94 & $<0.001$ \\
\hline 30 & 147 & -1.52 & -0.99 & $<0.001$ & 30 & 235 & -1.61 & -0.98 & $<0.001$ \\
\hline 40 & 103 & -1.37 & -0.96 & $<0.001$ & 40 & 97 & -1.24 & -0.95 & $<0.001$ \\
\hline 50 & 116 & -1.36 & -0.88 & $<0.05$ & 50 & 238 & -1.52 & -0.95 & $<0.02$ \\
\hline \multicolumn{6}{|c|}{ Nauplius stage VI } & \multicolumn{4}{|c|}{ Nauplius II to cypris } \\
\hline 20 & 382 & -1.55 & -0.95 & $<0.001$ & 20 & 1135 & -1.58 & -0.98 & $<0.001$ \\
\hline 30 & 433 & -1.63 & -0.98 & $<0.001$ & 30 & 1118 & -1.58 & -0.99 & $<0.001$ \\
\hline 40 & 366 & -1.50 & -0.94 & $<0.001$ & 40 & 933 & -1.45 & -0.97 & $<0.001$ \\
\hline 50 & 404 & -1.44 & -0.99 & $<0.01$ & 50 & 796 & -1.34 & -0.99 & $<0.01$ \\
\hline
\end{tabular}

Mortality (except at $6{ }^{\circ} \mathrm{C}$ ) was lowest at $20 \% \mathrm{~S}$ (Fig. 4). At $10 \% \mathrm{~S}$, most of the larvae died after a few days (at $6^{\circ}, 9^{\circ}$ and $24^{\circ} \mathrm{C}$ ), and only a small percentage reached the cypris stage at $12^{\circ}$ and $18{ }^{\circ} \mathrm{C}$ ( 2 and $6 \%$, respectively). Mortality at $20-40 \%$ S was lowest at $24^{\circ} \mathrm{C}$ and increased with decreasing water temperature.

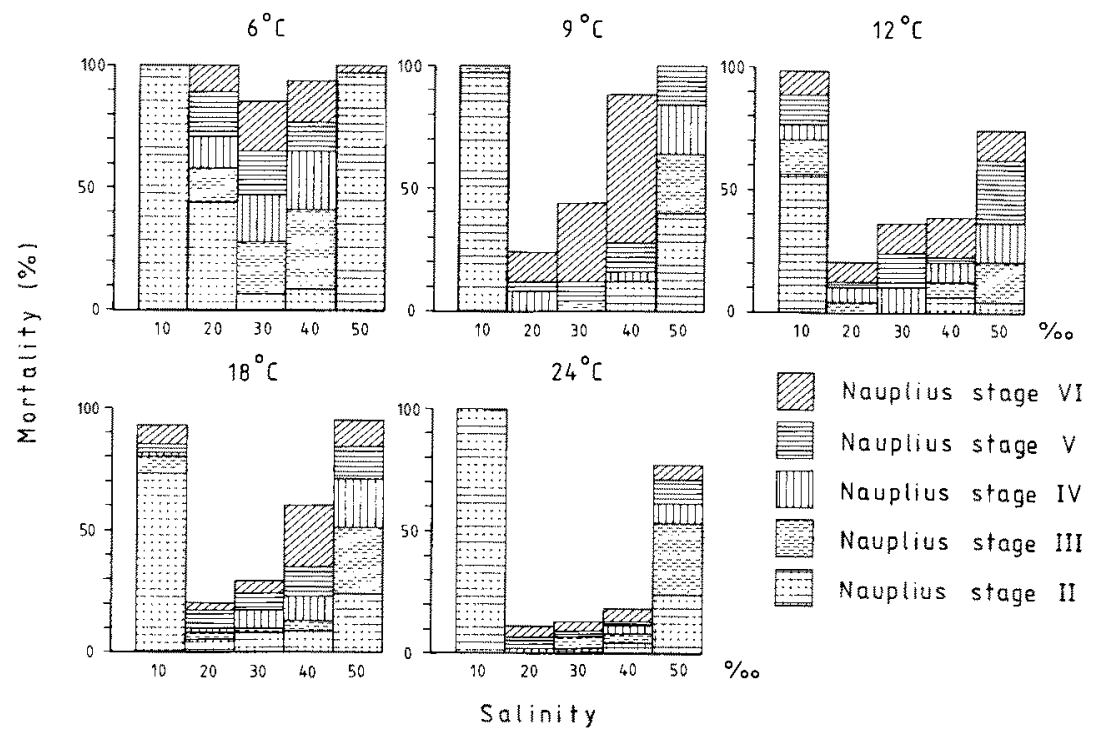

Fig. 4. Mortality of the naupliar stages of Elminius modestus from Helgoland in relation to water temperature and salinity 
Table 2. Carapace size (breadth, $\mu \mathrm{m}$ ) of the naupliar stages II to VI and carapace length $(\mu \mathrm{m})$ of the cypris stage at different combinations of water temperature and salinity for Elminius modestus from Helgoland (mean values $\pm 95 \%$ confidence intervals)

\begin{tabular}{|c|c|c|c|c|c|c|c|}
\hline \multicolumn{2}{|c|}{ Larval stage } & \multirow[t]{2}{*}{ II } & \multirow[t]{2}{*}{ III } & \multirow[t]{2}{*}{ IV } & \multirow[t]{2}{*}{ V } & \multirow[t]{2}{*}{ VI } & \multirow[t]{2}{*}{ Cypris } \\
\hline $\mathrm{T}\left({ }^{\circ} \mathrm{C}\right)$ & Salinity $(\%)$ & & & & & & \\
\hline \multirow[t]{4}{*}{6} & 20 & $176 \pm 3$ & $206 \pm 5$ & $251 \pm 8$ & $305 \pm 20$ & 380 & \\
\hline & 30 & $175 \pm 3$ & $209 \pm 4$ & $252 \pm 6$ & $317 \pm 12$ & $403 \pm 18$ & $566 \pm 32$ \\
\hline & 40 & $173 \pm 2$ & $205 \pm 5$ & $253 \pm 8$ & $314 \pm 15$ & $387 \pm 27$ & $552 \pm 67$ \\
\hline & 50 & & & & & & \\
\hline \multirow[t]{4}{*}{9} & 20 & $177 \pm 4$ & $204 \pm 4$ & $240 \pm 7$ & $304 \pm 9$ & $385 \pm 12$ & $556 \pm 21$ \\
\hline & 30 & $176 \pm 4$ & $210 \pm 3$ & $247 \pm 5$ & $313 \pm 8$ & $393 \pm 11$ & $597 \pm 36$ \\
\hline & 40 & $178 \pm 2$ & $200 \pm 4$ & $240 \pm 5$ & $304 \pm 7$ & $387 \pm 36$ & 550 \\
\hline & 50 & $169 \pm 5$ & $186 \pm 7$ & 247 & & & \\
\hline \multirow[t]{5}{*}{12} & 10 & $173 \pm 6$ & $213 \pm 9$ & $243 \pm 11$ & $309 \pm 8$ & 366 & 586 \\
\hline & 20 & $178 \pm 4$ & $215 \pm 7$ & $263 \pm 4$ & $317 \pm 7$ & $387 \pm 9$ & $570 \pm 15$ \\
\hline & 30 & $175 \pm 4$ & $209 \pm 5$ & $264 \pm 6$ & $327 \pm$ & $392 \pm 10$ & $567 \pm 14$ \\
\hline & 40 & $172 \pm 4$ & $203 \pm 4$ & $250 \pm 6$ & $312 \pm 7$ & $384 \pm 8$ & $569 \pm 21$ \\
\hline & 50 & $174 \pm 4$ & $200 \pm 6$ & $249 \pm 9$ & $311 \pm 12$ & $389 \pm 9$ & $574 \pm 19$ \\
\hline \multirow[t]{5}{*}{18} & 10 & $173 \pm 4$ & $209 \pm 7$ & $265 \pm 9$ & $306 \pm 16$ & $373 \pm 35$ & $484 \pm 24$ \\
\hline & 20 & $175 \pm 4$ & $212 \pm 5$ & $293 \pm 5$ & $317 \pm 8$ & $385 \pm 8$ & $562 \pm 26$ \\
\hline & 30 & $179 \pm 4$ & $204 \pm 6$ & $257 \pm 9$ & $314 \pm 9$ & $390 \pm 9$ & $583 \pm 39$ \\
\hline & 40 & $172 \pm 3$ & $202 \pm 5$ & $251 \pm 5$ & $313 \pm 5$ & $380 \pm 9$ & $558 \pm 12$ \\
\hline & 50 & $173 \pm 4$ & $186 \pm 8$ & $239 \pm 10$ & $306 \pm 8$ & $368 \pm 22$ & $537 \pm 17$ \\
\hline \multirow[t]{4}{*}{24} & 20 & $174 \pm 2$ & $218 \pm 3$ & $266 \pm 4$ & $317 \pm 6$ & $365 \pm 7$ & $537 \pm 11$ \\
\hline & 30 & $173 \pm 4$ & $210 \pm 3$ & $260 \pm$ & $311 \pm$ & $367 \pm 7$ & $542 \pm 12$ \\
\hline & 40 & $169 \pm 4$ & $209 \pm 3$ & $251 \pm 4$ & $309 \pm 6$ & $356 \pm 7$ & $511 \pm 14$ \\
\hline & 50 & $173 \pm 5$ & $201 \pm 6$ & $251 \pm 6$ & $307 \pm 5$ & $360 \pm 9$ & $520 \pm 13$ \\
\hline
\end{tabular}

Carapace size of the naupliar stages and the carapace length of the cypris larvae at different combinations of water temperature and salinity are given in Table 2 . The effect of temperature and salinity on carapace size was most obvious in the nauplius stage VI. There was generally a gradual decrease in size from $6^{\circ}$ to $18^{\circ} \mathrm{C}$ and a stronger reduction from $18^{\circ}$ to $24^{\circ} \mathrm{C}$. The largest exuviae for each temperature were always found at $30 \% \mathrm{~S}$ (Fig. 5). Towards lower and higher salinities there was a clear reduction in size. Carapace size varied little at $24^{\circ} \mathrm{C}$, although there was a trend towards smaller carapace size at higher salinites.

\section{New Zealand populations}

The influence of water temperature and salinity in the experiments carried out at Helgoland on single naupliar stages II-VI of the three N.Z. populations is shown in Figure 6. Developmental time and the salinity influence thereon increased with decreasing water temperature. The temperature influence on total larval development from nauplius II to the cypris could be described for all populations with a power function (Table 3A. Fig. 11). The regression lines for the Helgoland experiments concur well with 


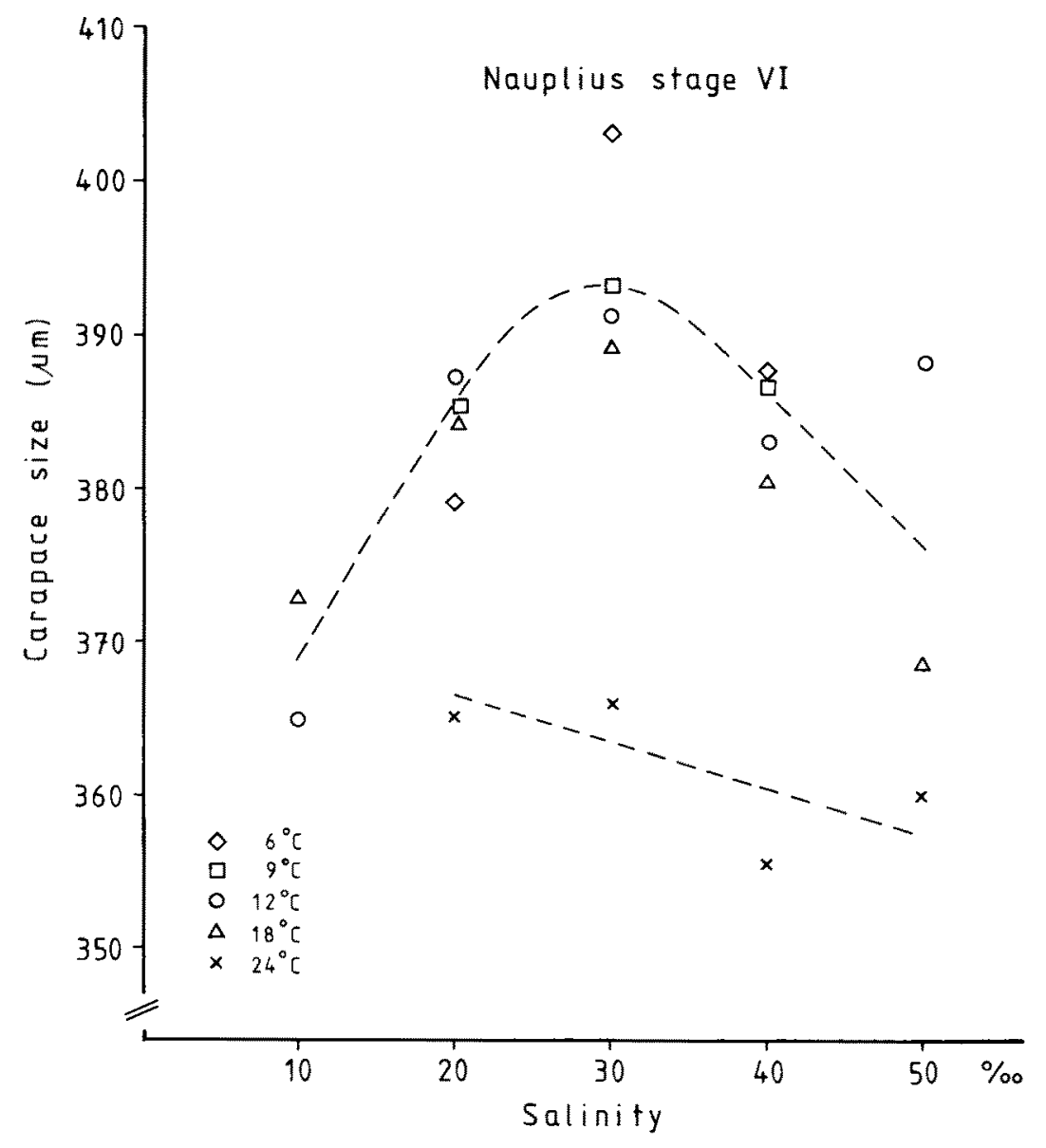

Fig. 5. Carapace size of the VI. nauplius stage of Elminius modestus from Helgoland at different combinations of temperature and salinity

the developmental duration of the experiments at the Marine Institutes in Portobello and Leigh at $18^{\circ} \mathrm{C}$ (Figs 7 and 8). The shift in developmental time towards shorter spans at low water temperatures and prolonged development at high temperatures may have been caused by temperature changes due to handling of the culture bowls (see Materials and Methods). A comparison of the temperature influence at the three tested salinities for the Portobello, Leigh, and Doubtless Bay population gave no significant differences, except for the Portobello population between $20 \% \mathrm{~S}$ and $30 \% \mathrm{~S}$ or $40 \% \mathrm{~S}$ (Table $4 \mathrm{~A}$ ). There were no significant differences between the two North Island populations (Table $4 \mathrm{~B}$ ), so that these data could be pooled (regression constants see Table $3 \mathrm{~B}$ ). The Portobello population was significantly different from the Leigh and Doubtless Bay populations at $30 \% \mathrm{~S}$ (Table $4 \mathrm{~B}$ ). A comparison of the Portobello data with that of the North Island (pooled data of Leigh and Doubtless Bay) showed no significant differences, 


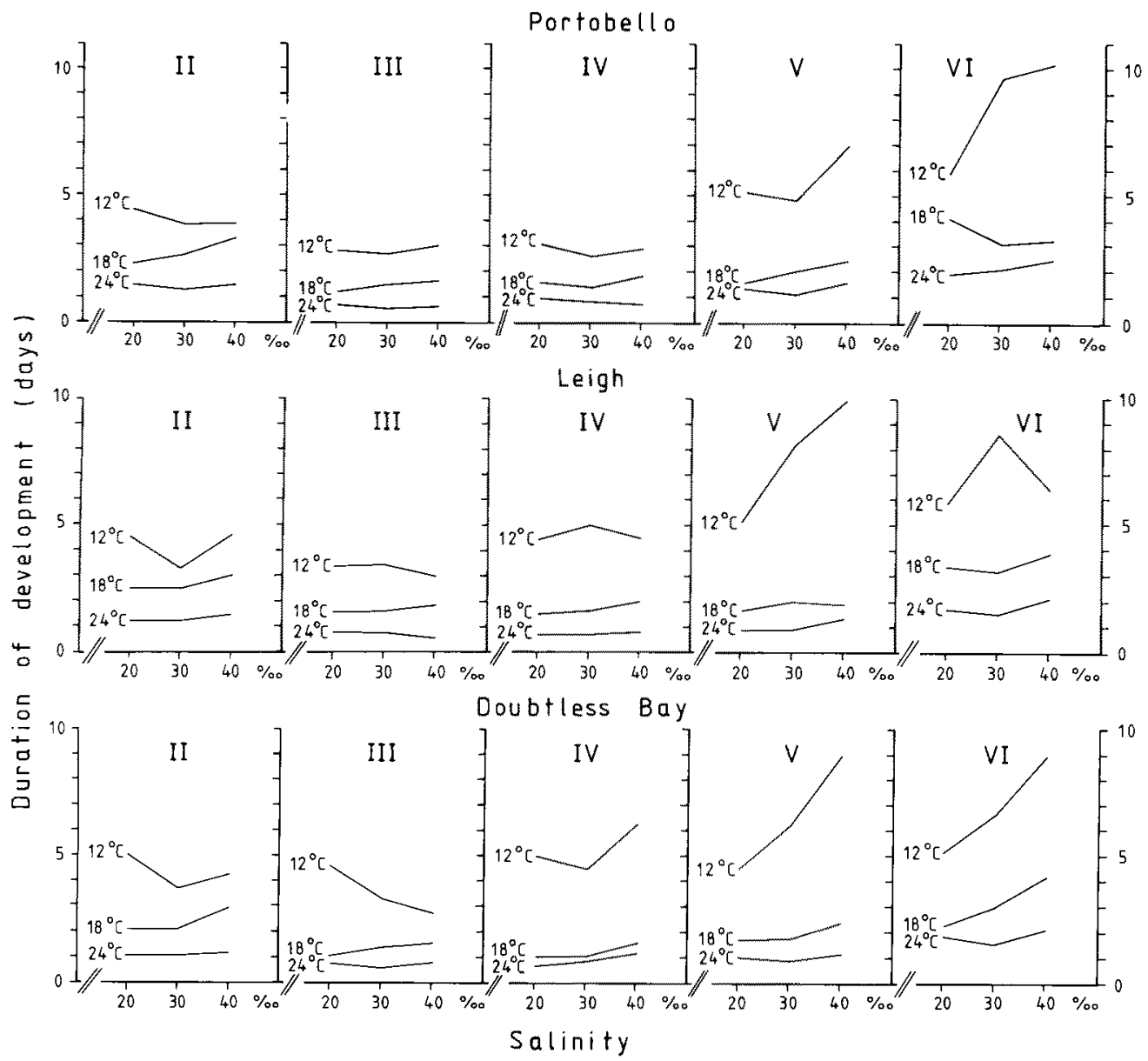

Fig. 6. Developmental time of the naupliar stages of Elminius modestus from New Zealand (experiments carried out at Helgoland) at different combinations of temperature and salinity (days, mean values)

and all data of the three N.Z. populations were pooled for comparison with the Helgoland data (Table 3 C, Fig. 11).

Mortality of the single naupliar stages of the N.Z. populations are given in the Figures 9 (experiments carried out in N.Z.) and 10 (experiments carried out in Helgoland). The extremely high mortalities in the Portobello experiments at $12^{\circ}, 15^{\circ}, 18^{\circ}$ and $24^{\circ} \mathrm{C}$ (Fig. 9) might have been caused by contamination with formalin, which had previously been used in the culture room. The developmental duration did not seem to be affected by this (Fig. 7). The experiments at $16^{\circ} \mathrm{C}$, carried out in a constanttemperature room, showed much lower mortality, although it was still higher than in the control experiments in Helgoland (Fig. 10). Normally, mortality was lowest at $24^{\circ} \mathrm{C}$ and increased with decreasing temperature. In both experiments, mortality was highest considering all temperatures at $40 \% \mathrm{~S}$, and it was extremely high at $12^{\circ} \mathrm{C}$. 
Table 3. Values of the power function ( $D=b t^{\mathrm{m}}$ ) for thermal influence $(\mathrm{t})$ on the duration of larval development (D) of Elminius modestus from three New Zealand populations (experiments carried out at Helgoland) for the temperature interval $12^{\circ}$ to $24^{\circ} \mathrm{C}$ at 20,30 , and $40 \% \mathrm{~S}$ (b and $\mathrm{m}$ are constants, $\mathrm{r}=$ correlation coefficient, $\mathrm{p}=$ confidence interval). Comprehension of the data for the North Island populations (Part B) is based on comparison of the regression slopes (Table 4). Since there were no significant differences between the pooled data of the North Island populations and Portobello all data could be comprehended (Part C)

\begin{tabular}{|c|c|c|c|c|c|}
\hline & Salinity $(\%)$ & $\mathrm{b}$ & $\mathrm{m}$ & r & $\mathrm{P}$ \\
\hline \multirow[t]{12}{*}{ (A) } & \multicolumn{5}{|l|}{ Portobello } \\
\hline & 20 & 1910 & -1.79 & -0.9999 & $<0.001$ \\
\hline & 30 & 3381 & -1.99 & -0.9998 & $<0.02$ \\
\hline & 40 & 3587 & -1.97 & -0.9999 & $<0.001$ \\
\hline & \multicolumn{5}{|l|}{ Leigh } \\
\hline & 20 & 4647 & -2.12 & -0.9980 & $<0.05$ \\
\hline & 30 & 12695 & -2.45 & -0.9997 & $<0.02$ \\
\hline & 40 & 5580 & -2.12 & -0.9991 & $<0.05$ \\
\hline & \multicolumn{5}{|l|}{ Doubtless Bay } \\
\hline & 20 & 4767 & -2.16 & -0.9884 & $<0.1$ \\
\hline & 30 & 7266 & -2.29 & -0.9998 & $<0.02$ \\
\hline & 40 & 10260 & -2.32 & -0.9991 & $<0.05$ \\
\hline \multirow[t]{4}{*}{ (B) } & \multicolumn{5}{|c|}{ Comprehended data for the North Island populations: } \\
\hline & 20 & 4770 & -2.14 & -0.9906 & $<0.001$ \\
\hline & 30 & 9604 & -2.37 & -0.9951 & $<0.001$ \\
\hline & 40 & 7570 & -2.22 & -0.9979 & $<0.001$ \\
\hline \multirow[t]{2}{*}{ (C) } & \multicolumn{5}{|c|}{ Comprehended data for the New Zealand populations: } \\
\hline & & 5203 & -2.13 & -0.9821 & $<0.001$ \\
\hline
\end{tabular}

Table 4. Comparison of the regression slope $(\mathrm{m})$ given in Table 3 for the thermal influence on larval development for the three tested populations of Elminius modestus from New Zealand (experiments carried out at Helgoland). Comparison of regression coefficients after Sachs (1976). A: thermal influence at the tested salinities, $\mathrm{B}$ : between populations

\begin{tabular}{|c|c|c|}
\hline \multicolumn{2}{|r|}{ A } & B \\
\hline \multicolumn{2}{|c|}{ Salinity $(\%)$} & Salinity $(\%)$ \\
\hline \multicolumn{2}{|c|}{ Portobello } & Portobello vs. Leigh \\
\hline \multicolumn{2}{|c|}{20 vs. $30 p<0.05$} & $20 \quad$ n.s. \\
\hline \multicolumn{2}{|c|}{20 vs. 40 p $<0.05$} & $30 \mathrm{p}<0.05$ \\
\hline 30 vs. 40 & n.s. & $40 \quad$ n.s. \\
\hline \multicolumn{2}{|l|}{ Leigh } & Portobello vs. Doubtless Bay \\
\hline 20 vs. 30 & n.s. & 20 n.s. \\
\hline 20 vs. 40 & n.s. & $30 \mathrm{p}<0.05$ \\
\hline 30 vs. 40 & n.s. & $40 \quad$ n.s. \\
\hline \multicolumn{2}{|c|}{ Doubtless Bay } & Leigh vs. Doubtless Bay \\
\hline 20 vs. 30 & n.s. & $20 \quad$ n.s. \\
\hline 20 vs. 40 & n.s. & n.s. \\
\hline 30 vs. 40 & n.s. & n.s. \\
\hline
\end{tabular}




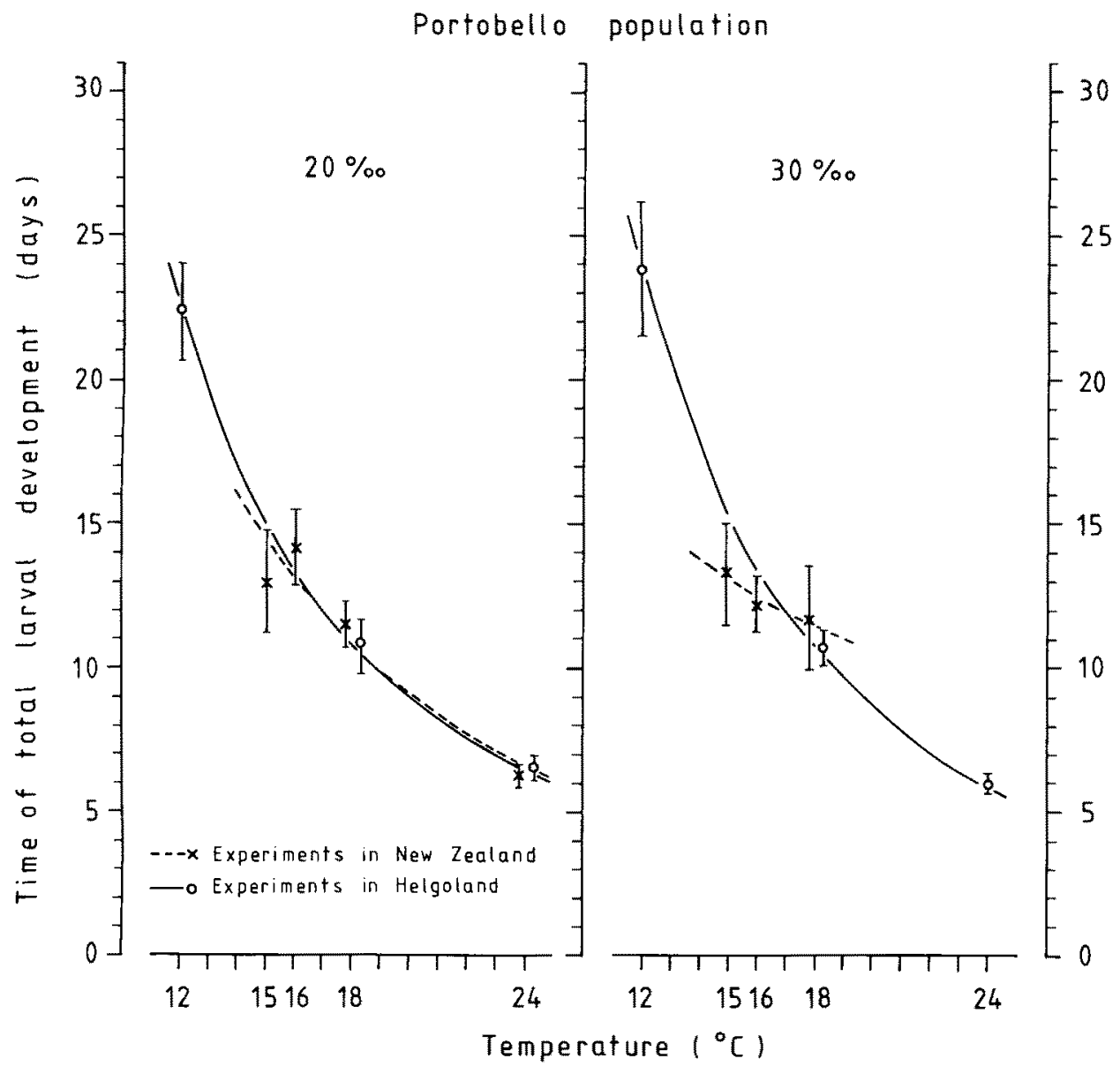

Fig. 7. Comparison of the time span for total larval development in the Portobello experiments (x) and in the control experiments at Helgoland (o) (mean value \pm standard deviations)

The salinity influence on growth rate was in general similar to the Helgoland population (Harms, 1985), but because of the smaller temperature and salinity ranges these trends were less obvious. In all experiments, the carapace size decreased with increasing temperature. The larvae from the Portobello population were always much smaller than larvae from the North Island populations (Fig. 12).

\section{Comparison of the antipodean populations}

The regression constants for the Helgoland population (pooled data) are given, for better comparison, for the same temperature interval $\left(12^{\circ}-24^{\circ} \mathrm{C}\right.$, Table 5) as for the N.Z. populations. The populations of Leigh and Doubtless Bay showed significant differences to the Helgoland population at 20 and $30 \% \mathrm{~S}$ (Table 6), which is the natural salinity range for larvae of Elminius modestus in the field. Comparison of the pooled North 


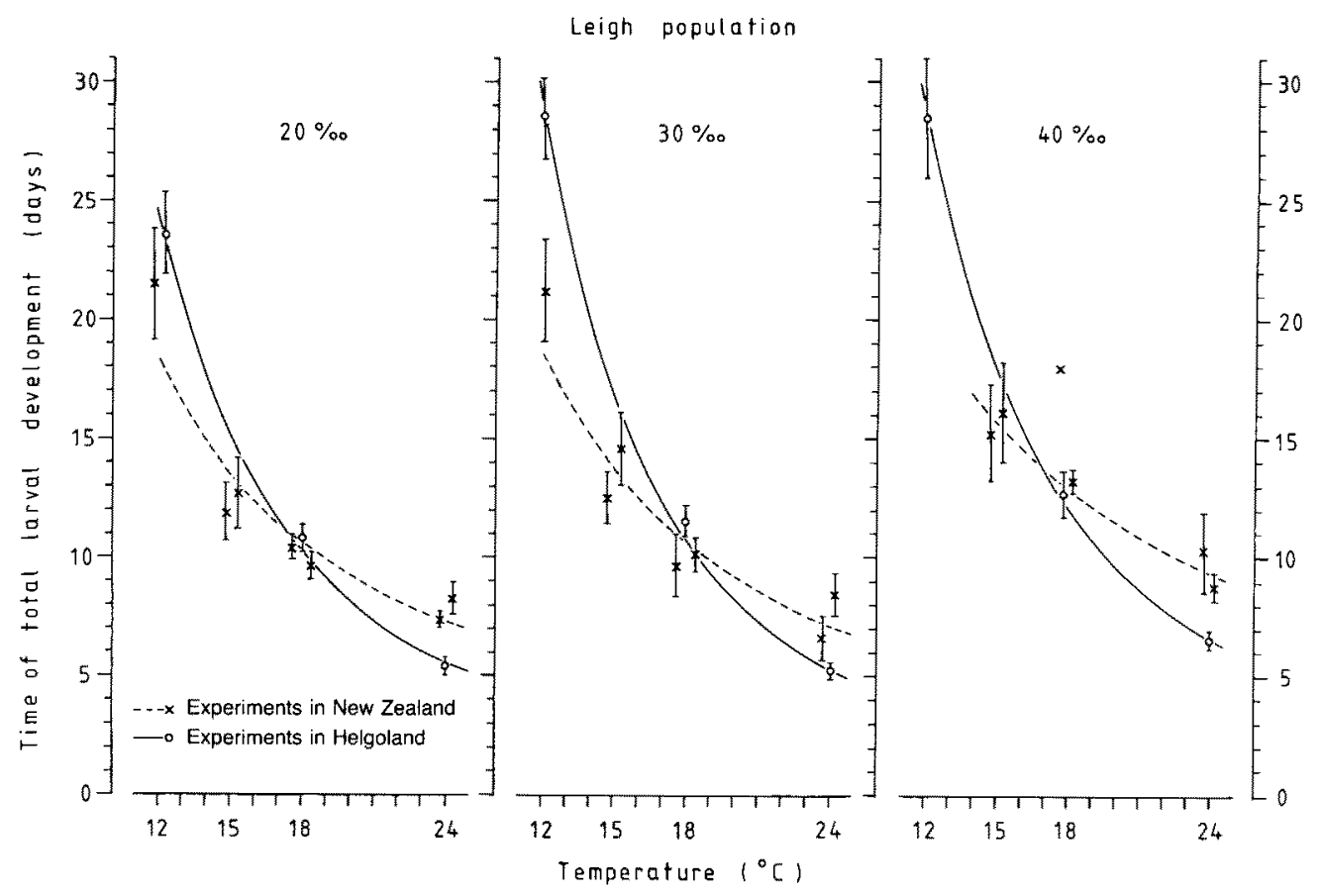

Fig. 8. Comparison of the time span for total development in the Leigh experiments ( $\mathrm{x}$ ) and in the control experiments at Helgoland $(0)$ [mean values \pm standard deviations]

Island populations data, however, showed significant differences at all tested salinities. No differences were found between the Portobello and Helgoland population, which have similar natural temperature ranges. As the data for the Portobello population were not significantly different from the pooled North Island populations data, it was possible to compare the N.Z. populations as a whole with the Helgoland population (Table 6, Fig. 11). The antipodean populations showed highly significant differences in the

Table 5. Values of the power function ( $D=\mathrm{b} \mathrm{t}^{\mathrm{m}}$ ) for thermal influence (t) on the duration of larval development (D) of Elminius modestus from Helgoland for the thermal interval of $12^{\circ}$ to $24^{\circ} \mathrm{C}$ and 20,30 and $40 \% \mathrm{~S}$. Comprehension of the data based on comparison of regression slopes, which showed no significant differences in temperature influence at the tested salinities

\begin{tabular}{|ccccc|}
\hline Salinity (\%) & $\mathrm{b}$ & $\mathrm{m}$ & $\mathrm{r}$ & $\mathrm{p}$ \\
\hline Helgoland $12-24^{\circ} \mathrm{C}$ & & & & \\
20 & 620 & -1.36 & -0.973 & $<0.01$ \\
30 & 990 & -1.54 & -0.962 & $<0.01$ \\
40 & 892 & -1.44 & -0.911 & $<0.02$ \\
& & & & \\
Helgoland $12-24^{\circ} \mathrm{C}$ (all data comprehended) & & -0.892 & $<0.001$ \\
& 1225 & -1.56 & & \\
\hline
\end{tabular}




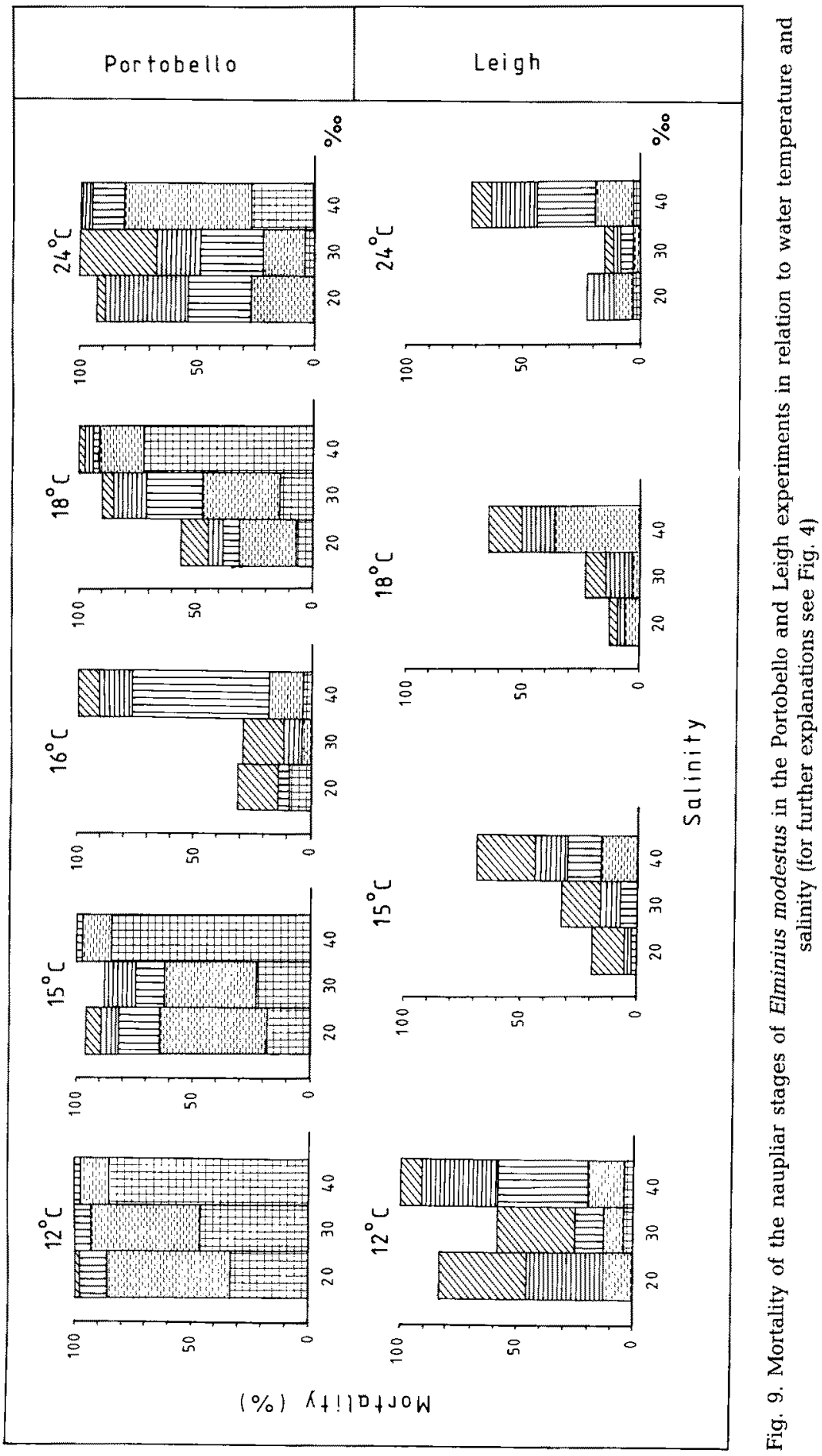



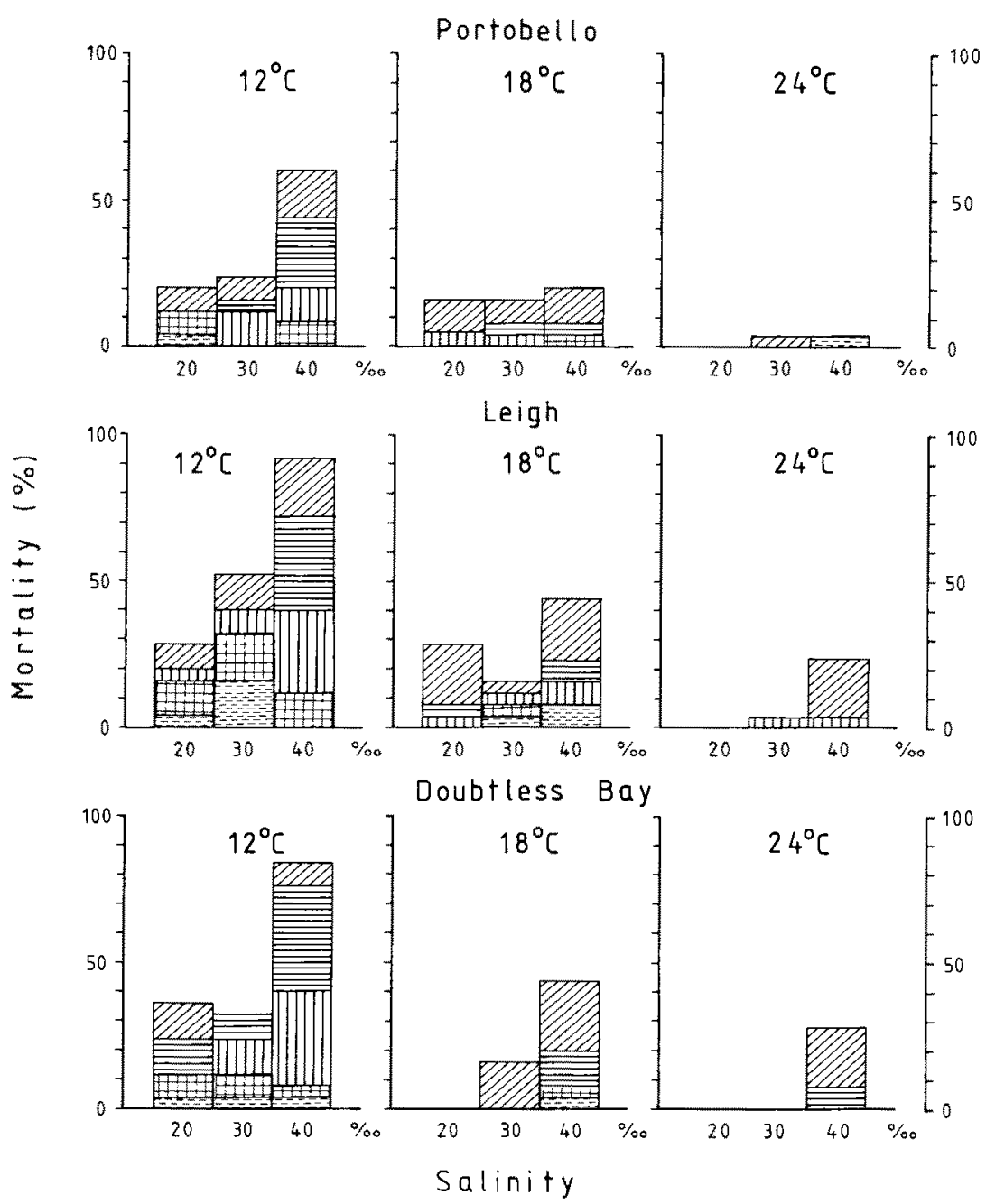

Fig. 10. Mortality of the naupliar stages of Elminius modestus from New Zealand (experiments carried out at Helgoland) in relation to water temperature and salinity (for further explanations see Fig. 4)

temperature influence on the duration of the larval development. Similarly, the $Q_{10^{-}}$ values $\left(12^{\circ}-24^{\circ} \mathrm{C}\right)$ showed a stronger temperature influence in the N.Z. population than in the Helgoland population (Table 7).

Another difference was found by comparing the carapace size of the naupliar stages. The N.Z. populations were much smaller in nauplius II (Fig. 12), which is especially true for the Portobello larvae. This difference in carapace size was found throughout the larval development up to the VI. nauplius stage (Harms, 1985). The variation in size of the VI. nauplius stage (Fig. 12) was caused by the influence of temperature and salinity. 
Table 6. Comparison of the thermal influence on larval development of Elminius modestus from New Zealand with those from Helgoland (after Sachs, 1976)

\begin{tabular}{|c|c|c|c|c|}
\hline \multicolumn{2}{|c|}{ Helgoland vs. Portobello } & \multicolumn{3}{|c|}{ Helgoland vs. Leigh } \\
\hline $20 \%$ & n.s. & $20 \%$ & $\mathrm{p}<0.02$ & \\
\hline $30 \%$ & n.s. & $30 \%$ & $\mathrm{p}<0.05$ & \\
\hline $40 \%$ & n.s. & $40 \%$ & n.s. & \\
\hline \multicolumn{2}{|c|}{ Helgoland vs. Doubtless Bay } & \multicolumn{3}{|c|}{ Helgoland vs. Leigh and Doubtless Bay } \\
\hline $20 \%$ & $p<0.02$ & $20 \%$ & $\mathrm{p}<0.01$ & \\
\hline $30 \%$ & $p<0.05$ & $30 \%$ & $\mathrm{p}<0.01$ & \\
\hline $40 \%$ & n.s. & $40 \%$ & $\mathrm{p}<0.05$ & \\
\hline \multirow{6}{*}{\multicolumn{4}{|c|}{$\begin{array}{l}\text { Helgoland (all data comprehended) vs. Portobello } 20 \% \\
\text { Helgoland (all data comprehended) vs. Portobello } 30 \text { and } 40 \% \\
\text { Helgoland vs. Leigh (all data comprehended) } \\
\text { Helgoland vs. Doubtless Bay (all data comprehended) } \\
\text { Helgoland vs. Leigh and Doubtless Bay (all data comprehended) } \\
\text { Helgoland vs. New Zealand (all data comprehended) }\end{array}$}} & n.s. \\
\hline & & & & n.s. \\
\hline & & & & $\mathrm{p}<0.05$ \\
\hline & & & & $\mathrm{p}<0.05$ \\
\hline & & & & $\mathrm{p}<0.005$ \\
\hline & & & & $\mathrm{p}<0.001$ \\
\hline
\end{tabular}

Table $7 . Q_{10}$-values for the influence of temperature on the duration of total larval development from nauplius II to the cypris stage of Elminius modestus

\begin{tabular}{|lrlllll|}
\hline \multicolumn{2}{c}{ Salinity (\%o) } & 10 & 20 & 30 & 40 & 50 \\
\hline Helgoland & $6-24^{\circ} \mathrm{C}$ & 2.32 & 3.38 & 3.38 & 3.06 & 2.85 \\
Helgoland & $12-24^{\circ} \mathrm{C}$ & & 2.20 & 2.45 & 2.25 & 2.23 \\
Portobello $12-24^{\circ} \mathrm{C}$ & & 2.81 & 3.16 & 3.11 & \\
Leigh & $12-24^{\circ} \mathrm{C}$ & & 3.42 & 4.12 & 3.41 & \\
Doubtless Bay $12-24^{\circ} \mathrm{C}$ & & 3.41 & 3.75 & 3.85 & \\
\hline
\end{tabular}

All four populations showed similar growth rates during larval development (Harms, 1985).

Observation of individual larvae showed that occasionally an intermediate stage between nauplius VI and the cypris occurred [Helgoland population: $12{ }^{\circ} \mathrm{C}, 30 \% \mathrm{~S}(1 \times)$; Portobello population: $16^{\circ} \mathrm{C}, 30 \% \mathrm{~S}(1 \times)$; Leigh population: $12{ }^{\circ} \mathrm{C}, 30 \% \mathrm{~S}(4 \times) ; 15^{\circ} \mathrm{C}$, $\left.40 \% \mathrm{~S}(2 \times), 15^{\circ} \mathrm{C}, 20 \% \mathrm{~S}(1 \times) ; 24^{\circ} \mathrm{C}, 30 \% \mathrm{~S}(1 \times)\right]$. This stage had the limbs of the nauplius and the thoracic appendages of the cypris. The carapace was more or less cypris-like. Tighe-Ford (1977) described a similar intermediate stage for the larval development of $E$. modestus in the presence of juvenile hormones. A similar stage was also found in Semibalanus balanoides (Harms, unpublished observation) at $12{ }^{\circ} \mathrm{C}$ and $30 \% \mathrm{~S}(1 \times)$. This stage was mainly inactive with no further moulting, and larvae always died after a couple of days. 


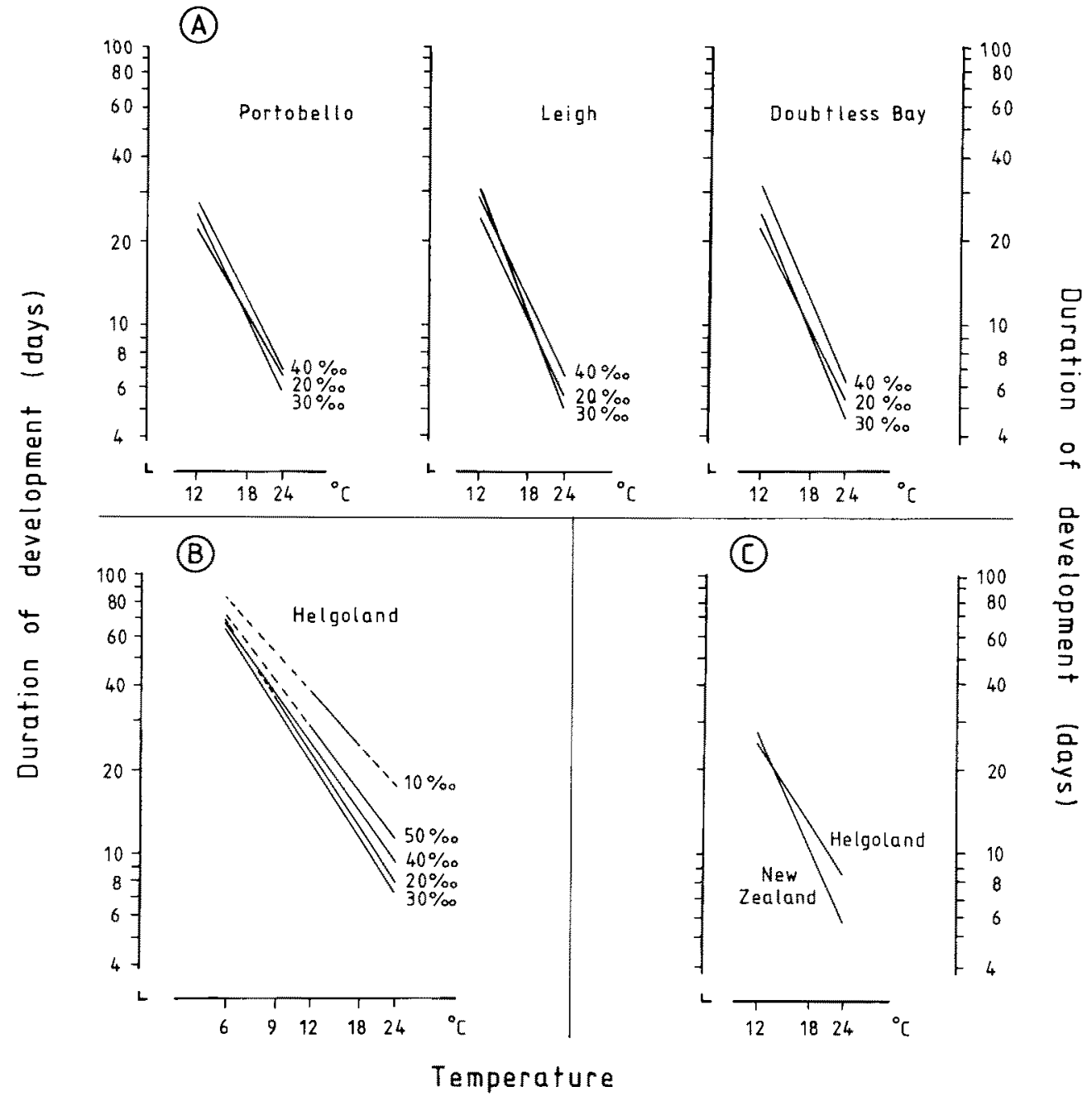

Fig. 11. Duration of total larval development (days) from nauplius II to the cypris stage, calculated from the power functions (Tables: 1, 3 and 5), for Elminius modestus from Helgoland and New Zealand

\section{DISCUSSION}

The adults of Elminius modestus, a euryhaline species, are active between 19 to $40 \%$ S (Barnes \& Barnes, 1974; Davenport, 1976). E. modestus larvae hatch only at salinities above $21 \%$ S, but are still mobile at $9 \%$ S (Cawthorne \& Davenport, 1980). Data of the salinity range in which the larvae of $E$. modestus develop successfully to cypris are missing. Only little is known about the salinity tolerance of the first nauplius stage. Bhatnagar \& Crisp (1965) proposed a tolerance limit of 12 to $15 \%$ S. Davenport \& Cawthorne (1978) reported that larvae which are adapted to low salinities had a 


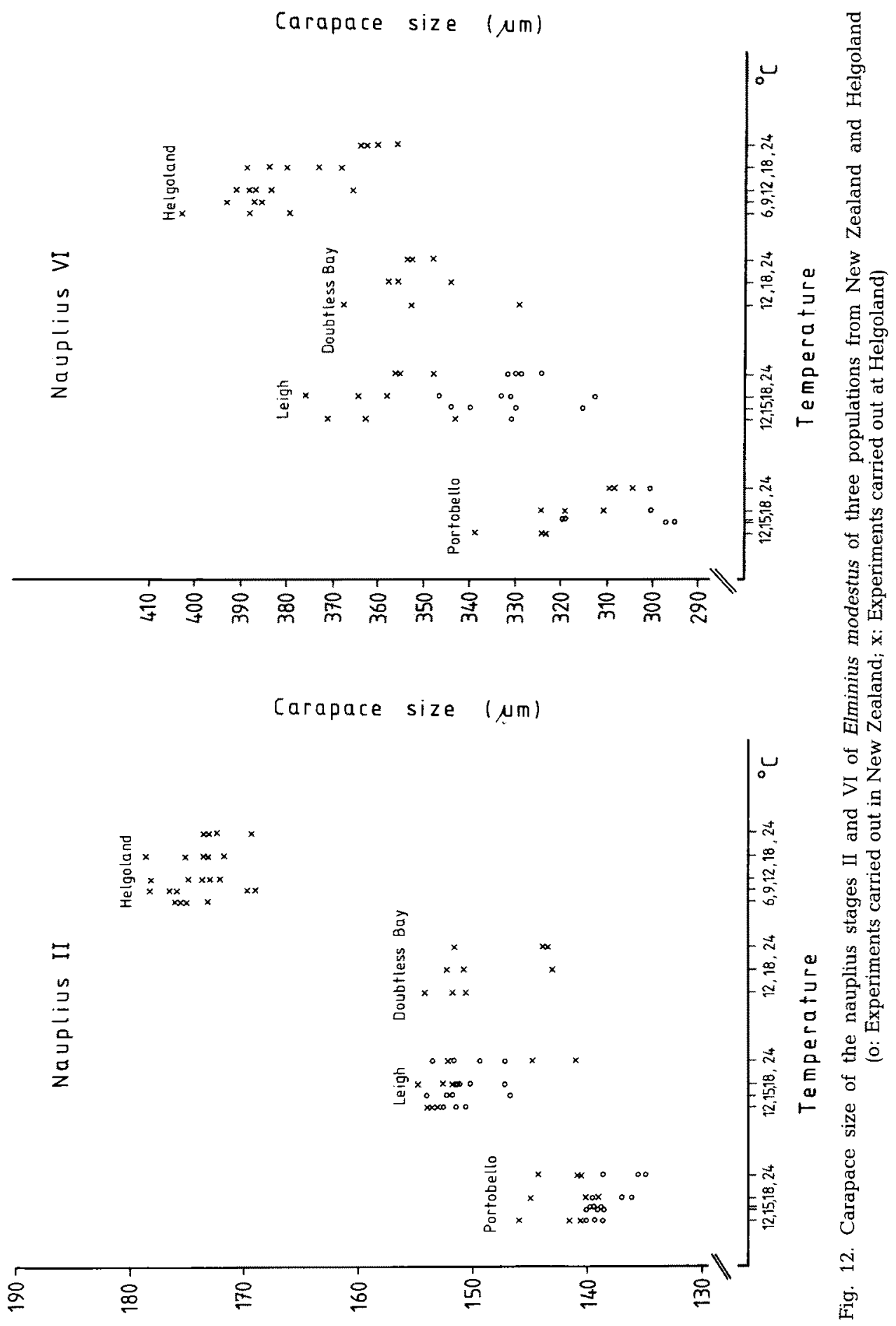


tolerance limit of $6.7 \% \mathrm{~S}$. Lance (1964) gave $10.3 \% \mathrm{~S}$ as the lower tolerance limit of the VI. stage of E. modestus. All these experiments were carried out with freshly hatched larvae or those from plankton hauls, data for the other naupliar stages are lacking. These present experiments showed that the larvae of $E$. modestus can be reared to the cypris without any adaptation in a salinity range of 10 to $50 \% \mathrm{~S}\left(12^{\circ}-18{ }^{\circ} \mathrm{C}\right)$. The reduced salinity tolerance at extreme temperatures $\left(6^{\circ}, 9^{\circ}\right.$ and $\left.24^{\circ} \mathrm{C}\right)$, and low mortality of the nauplius stages between 20 to $40 \% \mathrm{~S}$ correspond to the salinity ranges of the adults (Barnes \& Barnes, 1974; Davenport, 1976). Judging from the successful cypris metamorphosis to juveniles in all experimental sets (except at 10 and $50 \% \mathrm{~S}$ ), cypris seem to have similar tolerance limits as adults. The rearing of the larvae showed that developmental time at salinities which are normally found in the natural environment was slightly shorter than at extreme salinities $(10,40$ and $50 \% \mathrm{~S})$.

At the beginning of the experiments, nauplii (stage II) showed a temporary lack of activity at the extreme salinities (10 and $50 \%$ S), and recovered normally after 10 to 30 min. Some of the larvae lived for a long time (up to 25 days) without any further development. Low salinities in natural environments can be observed near water surfaces. Because of this inactivity, the larvae in nature are likely to sink from such low salinity conditions to deeper, more saline water layers. Similar behaviour was observed in decapods (Anger, 1985; Roberts, 1971). Larvae of E. modestus also tolerate high salinities, which may occur through evaporation in intertidal areas. This is especially important for E. modestus which settles in the upper part of the intertidal zone (Foster, $\left.1971 \mathrm{a}_{\mathrm{r}} \mathrm{b}\right)$.

Larval growth rate is influenced both by temperature and salinity. Tighe-Ford at al. (1970) and Crisp (1962) found similar temperature effects on larval size in laboratory culture and field studies. The largest carapace sizes were always found at $30 \% \mathrm{~S}$, which is close to natural salinity (Fig. 2).

The differences in larval size between the N.Z. populations are surprising, because the smallest larvae were found in the relatively cool area of the South Island. These results contrast with those of Barnes \& Barnes (1965 b) and Crisp (1962), who found increased larval size in cooler geographic areas. No differences in the carapace size of the nauplii occurred between the two North Island populations. The Helgoland larvae, which are subject to occasionally harsh winters (Crisp, 1964 a; Dörjes, 1980; Harms \& Anger, 1983; Ziegelmeier, 1964) and relatively low summer temperatures (Hickel \& Mangelsdorf, 1980), were always larger than those from N.Z.

Non-genetic adaptation during early stages can have a strong influence on later acclimation (for definition see Crisp \& Ritz, 1967; Kinne, 1964) and may influence the differences in naupliar size and developmental time between the antipodean populations. Acclimation to various predominate temperatures might also be responsible for the differences between the North and South Island populations of N.Z. (Table 4). The time span of three months at $15^{\circ} \mathrm{C}$ in a flow-through-system at Helgoland might not have been enough to reach identical acclimation conditions for the N.Z. populations. Although more than half the eventual level of acclimation in many groups is achieved in the first week (Crisp \& Ritz, 1967).

Earlier experiments, such as a comparison of cirral activity (Ritz \& Foster, 1968), and gel-electrophoretic examinations (Flowerdew, 1984) failed to find differences between populations of E. modestus from N.Z. and Europe. These results, the differences in larval 
development and larval size of the antipodean populations of E. modestus, are indications of a diverse temperature influence. The first evidence of a separation of Semibalanus balanoides into two distinct races in Europe and North America were based on differences in egg size (Crisp, 1964 b), time of embryonic development (Barnes \& Barnes, 1976; Crisp, 1959 b) and on different cirral activities (Southward, 1964). Only recently could these results be confirmed genetically by variations in allele frequencies (Flowerdew \& Crisp, 1975, 1976).

Extreme winters may act as a strong factor in the natural selection towards lower temperature adaptation in the Helgoland population. There have always been heavy reductions in population size of $E$. modestus during such winters in the inter- and subtidal area around Helgoland (Harms \& Anger, 1983; and unpublished observations for 1981, 1985 and 1986). Survival of the fittest seems to play a significant role in the development of temperature adaptation in the Helgoland population of $E$. modestus.

Acknowledgements. This research was supported by a grant from the "Studienstiftung des deutschen Volkes", who also supported the investigations in New Zealand. I am grateful to Dr. A. Buschinger (TH-Darmstadt) who supervised this work; and to Dr. O. Kinne, Dr. H.-P. Bulnheim (Biologische Anstalt Helgoland), Dr. J. Jillet (Marine Institute Portobello) and Dr. W. J. Ballentine (Marine Institute Leigh) who provided working facilities. In particular, I am very grateful to Dr. K. Anger, Dr. M. Barker and Dr. B. A. Foster for their helpful comments and fruitful discussions; also to B. Seeger for typing and to J. Selzer for correcting the manuscript. This paper is part of a dissertation (TH Darmstadt).

\section{LITERATURE CITED}

Anger, $K_{1}$ 1978. Development of a subtidal epifaunal community at the island of Helgoland. Helgoländer wiss. Meeresunters. 31, 457-470.

Anger, K., 1985. Influence of salinity on larval development of the spider crab, Hyas araneus, reared in the laboratory. - In: Marine biology of polar regions and effects of stress on marine organisms. Ed. by J. S. Gray \& M. E. Christiansen. Wiley, Chichester, 463-473.

Ballentine, W. J., 1983. Leigh climate report, the climate in 1983. - Leigh Lab. Bull. 17, 1-120.

Barnes, H. \& Barnes, M., 1960. Recent spread and present distribution of the barnacle Elminius modestus Darwin in north-west Europe. - Proc. zool. Soc. Lond. 135, 137-145

Barnes, H. \& Barnes, M., 1961. Recent spread and present distribution of the barnacle Elminius modestus Darwin in south-west Europe. - Glasg. Nat. 18, 121-129.

Barnes, H. \& Barnes, M., 1965a. Elminius modestus Darwin: Further European records. - Progr. Oceanogr. 3, 23-30.

Barnes, H. \& Barnes, M., 1965b. Egg size, nauplius size, and their variation with local, geographical, and specific factors in some common cirripedes. - J. Anim. Ecol. 34, 391-402.

Barnes, H. \& Powell, H. T., 1966. Notes on the occurrence of Balanus balanoides, Elminius modestus, Fucus serratus and Littorina littoralis at Arcachon, France, in 1963 and 1964. - In: Some contemporary studies in marine science. Ed. by H. Barnes. Allen \& Unwin, London, $107-111$.

Barnes, H. \& Barnes, M., 1969. Elminius modestus Darwin: Records of its present distribution and abundance in the Baie de St. Malo and in the region of St Jean-De-Luz. - J. exp. mar. Biol. Ecol. 3, 156-161.

Barnes, H. \& Stone, R. L., 1972. New record for Elminius modestus Darwin, 1854, in western Scotland (Cirripedia, Thoracica). - Crustaceana 23, 309-310.

Barnes, H. \& Barnes, M., 1974. The responses during development of the embryos of some common cirripedes to wide range of salinity. - J. exp. mar. Biol. Ecol. 15, 197-202.

Barnes, H. \& Barnes, M., 1976. The rate of development of the embryos of Balanus balanoides (L.) from a number of European and American populations and the designation of local races. J. exp. mar. Biol. Ecol. 24, 251-269. 
Barnes, H., Barnes, M. \& Klepal, W., 1972. Some cirripedes of the French Atlantic coast. - J. exp. mar. Biol. Ecol. 8, 187-194.

Bhatnagar, K. M. \& Crisp, D. J., 1965. The salinity tolerance of nauplius larvae of cirripedes. - J. Anim. Ecol. 34, 419-428.

Bishop, M. W. H., 1947. Establishment of an immigrant in British coastal waters. - Nature, Lond. $159,501$.

Bishop, M. W. H., 1954. Elminius modestus in France. - Nature, Lond. 173, 1145.

Boschma, H., 1948. Elminius modestus in the Netherlands. - Nature, Lond. 161, 403.

Cawthorne, D. F. \& Davenport, J., 1980. The effect of fluctuating temperature, salinity, and aerial exposure upon larval release in Balanus balanoides and Elminius modestus. - J. mar. biol. Ass. U.K. $60,367-377$.

Connell, J. H., 1955. Elminius modestus Darwin, a northward extension of range. - Nature, Lond. $175,954$.

Costlow, J. D. \& Bookhout, C. G., 1971. The effect of cyclic temperatures on larval development in the mud crab Rhithropanopeus harrisii. In: Fourth European Marine Biology Symposium. Ed. by D. J. Crisp. Univ. Press, Cambridge, 211-220.

Crisp, D. J., 1958. The spread of Elminius modestus Darwin in north-west Europe. - J. mar. biol. Ass. U.K. 37, 483-520.

Crisp, D. J, 1959a. A further extension of Elminius modestus Darwin on the west coast of France. Beaufortia 82, 37-39.

Crisp, D. J., 1959b. The rate of development of Balanus balanoides (L.) embryos in vitro. - J. Anim. Ecol. 28, 119-132.

Crisp, D. J., 1960. Northern limits of Elminius modestus in Britain. - Nature, Lond. 188, 681.

Crisp, D. J., 1962. The planktonic stages of the Cirripedia Balanus balanoides and Balanus balanus from north temperate waters. - Crustaceana 3, 207-221.

Crisp, D. J., 1964 a. The effect of the severe winter of 1962-63 on marine life in Britain. - J. Anim. Ecol. 33, 165-210.

Crisp, D. J., 1964b. Racial differences between North American and European forms of Balanus balanoides. - J. mar. biol. Ass. U.K. 44, 33-45.

Crisp, D. J. \& Ritz, D. A., 1967. Temperature acclimation in barnacles. - J. exp. mar. Biol. Ecol. 1, $236-246$.

Crisp, D. J. \& Southward, A. J., 1959. The further spread of Elminius modestus in the British Isles to 1959. - J. mar. biol. Ass. U.K. 38, 429-437.

Crow, J. F. \& Kimura, M., 1970. An introduction to population genetics theory. Harper \& Row, New York, $591 \mathrm{pp}$.

Davenport, J., 1976. A comparative study of the behavior of some balanomorph barnacles exposed to fluctuating seawater concentrations. - J. mar. biol. Ass. U.K. 56, 889-907.

Davenport, J. \& Cawthorne, D. F., 1978. An apparatus for the laboratory stimulation of environmental fluctuations in temperature, salinity and oxygen tension. - Lab. Pract. 27, 281-284.

DenHartog, C., 1953. Immigration, dissemination and ecology of Elminius modestus (Darwin) in the North Sea, especially along the Dutch coast. - Beaufortia 33, 9-20.

Den Hartog, C. 1956. Speculations on the immigration of the barnacle Elminius modestus in France. - Beaufortia 56, 141-142.

DenHartog, C., 1959. Die Seepocke Elminius modestus auf Helgoland. - Beaufortia 86, 207-209.

Dörjes, J., 1980. Auswirkungen des kalten Winters 1978/1979 auf das marine Macrobenthos. Natur Mus., Frankf. 110, 109-115.

Fischer-Piette, E. \& Forest, J., 1961. Nouveaux progrès du cirripede austral Elminius modestus Darwin sur les côtes atlantiques françaises et iberiques. - Crustaceana 2, 293-299.

Flowerdew, M. W., 1984. Electrophoretic comparison of the antipodean cirripede, Elminius modestus, with immigrant European populations. - J. mar. biol. Ass. U.K. 64, 625-635.

Flowerdew, M. W. \& Crisp, D. J., 1975. Esterase heterogeneity and an investigation into racial differences in the cirripede Balanus balanoides using acrylamide gel electrophoresis. - Mar. Biol. 33, 33-39.

Flowerdew, M. W. \& Crisp, D. J., 1976. Allelic esterase isozymes, their variation with season, position on the shore and stage of development in the cirripede Balanus balanoides. - Mar. Biol. $35,319-325$. 
Foster, B. A., 1971a. Desiccation as a factor in the intertidal zonation of barnacles. - Mar. Biol. 8 , 12-29.

Foster, B. A., 1971b. On the determinants of the upper limit of intertidal distribution of barnacles. J. Anim. Ecol. 40, 33-48.

Foster, B. A., 1978. The marine fauna of New Zealand: Barnacles (Cirripedia: Thoracica). - Mem. N.Z. oceanogr. Inst. $69,1-160$.

Foster, B. A., 1980. Biogeographic implication of a re-examination of some common shore barnacles of Australia and New Zealand. - N.Z. DSIR Inf. Ser. 137, 613-623.

Foster, B. A., 1982. Two new intertidal balanoid barnacles from eastern Australia. - Proc. Linn. Soc. N.S.W. 106, 21-32.

Harms, J., 1982. Untersuchungen zur Larvalentwicklung und zum Wachstum von Seepocken der Deutschen Bucht. Dipl. Arb., TH Darmstadt, $118 \mathrm{pp}$.

Harms, J., 1984. Influence of water temperature on larval development of Elminius modestus and Semibalanus balanoides (Crustacea, Cirripedia), - Helgoländer Meeresunters, 38, $123-134$.

Harms, J., 1985. Untersuchungen zum Lebenszyklus von Elminius modestus Darwin (Crustacea, Balanoidea). Diss., TH Darmstadt, $146 \mathrm{pp}$.

Harms, J. \& Anger, K., 1983. Seasonal, annual, and spatial variation in the development of hard bottom communities, - Helgoländer Meeresunters. 36, 137-150.

Hickel, W. \& Mangelsdorf, P., 1980. Phytoplankton, micronutrients, and salinity at Helgoland Roads in 1978. - Annls biol. Copenh. 35, 118-119.

Hiscock, K., Hiscock, S. \& Baker, J. M., 1978. The occurrence of the barnacle Elminius modestus in Shetland. - J. mar. biol. Ass. U.K. 58, 627-629.

Janke, K., 1986. Die Makrofauna und ihre Verteilung im Nordost-Felswatt von Helgoland. Helgoländer Meeresunters. 40, 1-55.

Jones, D. H., 1961. Elminius modestus on the south east coast of Scotland. - Nature, Lond. 190, 103-104.

Kinne, O., 1964. Non-genetic adaptation to temperature and salinity. - Helgoländer wiss. Meeresunters. 9, 433-458.

Kühl, H., 1963. Die Verbreitung von Elminius modestus (Darwin) (Cirripedia, Thoracia) an der Deutschen Küste. - Crustaceana 5, 99-111.

Lance, J,, 1964. The salinity tolerances of some estuarine planktonic crustaceans. - Biol. Bull. mar. biol. Lab., Woods Hole 127, 108-118.

Luckens, P. A., 1976. Settlement and succession on rocky shore at Auckland, North Island, New Zealand. - Mem. N.Z. oceanogr. Inst. 70, 1-63.

Moore, L. B., 1944. Some intertidal sessile barnacles of New Zealand. - Trans. Proc. R. Soc. N.Z.73, $315-334$.

Morton, J. E. \& Miller, M. C., 1968. The New Zealand Sea shore. Collins, London, 638 pp.

Powell, H. T., 1960. Elminius modestus Darwin on the isle of Cumbrae. - Nature, Lond. 185, $119-120$.

Ritz, D. A. \& Foster, B. A., 1968. Comparison of the temperature responses of barnacles for Britain, South Africa and New Zealand, with special reference to temperature acclimation on Elminius modestus. - J. mar. biol. Ass. U.K. 48, 545-558.

Roberts, M. H., 1971. Larval development of Pagurus longicarpus Say reared in the laboratory. II. Effects of reduced salinity on larval development. - Biol. Bull mar. biol. Lab., Woods Hole 190 , $104-116$.

Sachs, L., 1976. Angewandte Statistik. Springer, Berlin 545 pp.

Sastry, A. N., 1979. Metabolic adaption of Cancer irroratus developmental stages to cyclic temperatures, - Mar. Biol. 51, 243-250.

Slinn, D. J., 1968. Some hydrological observations in Auckland and Otago harbours. - Trans. R. Soc, N.Z. $2,79-97$.

Southward, A. J., 1964. The relationship between temperature and rhythmic cirral activity in some Cirripedia considered in connection with their geographical distribution. - Helgoländer wiss. Meeresunters. 10, 391-403.

Stubbings, H. G., 1950. Earlier records of Elminius modestus (Darwin) in British waters. - Nature, Lond, $166,277$.

Tighe-Ford, D. J., 1977. Effects of juvenile hormone analogues on larval metamorphosis in the 
barnacle Elminius modestus Darwin (Crustacea: Cirripedia). - J. exp. mar. Biol. Ecol. 26, $163-176$.

Tighe-Ford, D. J., Power, M. J. D. \& Vaile, D. C., 1970. Laboratory rearing of barnacles larvae for antifouling research. - Helgoländer wiss. Meeresunters. 20, 393-405.

Ziegelmeier, E., 1964. Einwirkungen des kalten Winters 1962/63 auf das Makrobenthos im Ostteil der Deutschen Bucht. - Helgoländer wiss. Meeresunters. 10, 276-282. 